\title{
Rural Poverty and Livelihood Changes under the Aquacultural Development around Tam Giang Lagoon, Central Vietnam
}

\author{
Nguyen Huu NGU* and KIM Doo-Chul** \\ * Graduate Student, Graduate School of Environmental Science, Okayama University; Okayama 700-8530, Japan. \\ ** Graduate School of Environmental Science, Okayama University; Okayama 700-8530, Japan. \\ E-mail:nguqld@yahoo.com*, kim@cc.okayama-u.ac.jp**
}

Received March 15, 2008; Accepted October 17, 2008

\begin{abstract}
This research attempts to clarify the characteristics of the "poor" households in Phu An Commune, located on the shore of Tam Giang Lagoon, Central Vietnam. To understand the socioeconomic background of poverty in the area, the authors examine the changes in agriculture as well as shrimp aquaculture since the adoption of "Doi Moi", an open-door policy, in 1986. Then, the constraints which make it difficult for them to escape from poverty are discussed. The results of this study show that agricultural and aquacultural changes have diversified the locals' livehoods. The positive changes are reflected in the decline of the number of "poor" households as well as in their evaluation of their lives compared with 20 years ago. Nevertheless, there are still many constraints which cause the "poor" households to remain poor in spite of the remarkable economic growth during the last 20 years. Insight into the detailed situation of poverty in the area is given through the categorization of the residents by their livelihood: mobile gear fishing (usually called "Sampan people"), fixed gear fishing, farming, farming and fishing, and service. In the process of the "Doi Moi" policy and following the introduction of shrimp aquaculture around 1999, the water surface of Tam Giang Lagoon, which used to be an open-access common resource, was allocated to individuals for their exclusive use and exploited mainly for shrimp aquaculture. Due to these drastic changes in local resource, the "Sampan people", who have been engaged in only fishery in Tam Giang Lagoon, have changed their position in the commune from the greatest beneficiaries to those of sacrifices. Now the poorest in this area are those who engage in mobile gear fishing, the "Sampan people".
\end{abstract}

Key words poverty, livelihood, Doi Moi, aquaculture, Sampan people, Tam Giang Lagoon, Vietnam

\section{Introduction}

Poverty is a state of deprivation involving multiple dimensions (Martin et al. 2003). There is no unique definition of poverty and, therefore, no perfect indicator to measure it. Limited income or limited opportunities to generate income; lack of assets to protect consumption in difficult times and vulnerability in the face of adverse shocks; few possibilities to convey demands and grievance to those who could address them and to participate in collective decision-making; a sense of humiliation and lack of respect by others, all these are aspects of poverty. The perception of poverty has evolved historically and varies considerably from one culture to another. Criteria for distinguishing the "poor" from the non-"poor" generally tend to reflect specific national priorities. Poverty has been considered as the condition that is said to exist when the people lack the means to satisfy their basic needs (Economic and Social Commission for Asia and the Pacific 1999). In Vietnam, a definition of poverty presented in the national program for hunger eradication and poverty reduction is also used as a reference. It is said that "Poverty is a situation where a part of the population cannot satisfy the bare necessities of life and has a lower living standard than the average living standard of the community in all aspects" (Ministry of Labor, Invalids and Social Affairs 2001).

Along with the above theoretical definition for poverty in Vietnam, the Government also prevalently uses an operational definition of the poor to identify the numbers of poor households and make a list of them. Based on the Decision 170/2005/QD-TTg of Vietnam's Prime Minister in 2005, a household is considered as "poor" if its income is under 200,000 VND (approximately 12.6 USD with the exchange rate of the year of 2005, 1 USD $=15,900 \mathrm{VND}$ ) per month per person in rural area, or 260,000 VND (approximately 16.4 USD) per month per person in urban area.

According to the above operational criteria for identifying the "poor", about 90 percent of the "poor" 
household lives in rural areas, among which over 80 percent are farmers (Ministry of Planning and Investment 2002). Therefore, poverty in Vietnam can be generally said to be a rural phenomenon.

Poverty reduction has been a central goal of the Vietnamese Government since the unification in 1975, especially after "Doi Moi"; a driving force behind the economic reforms initiated in 1986 (Markanday 2004). The process of renovation and acceleration of rapid economic growth in parallel with implementation of the task of poverty reduction and social equity from 1986 has narrowed the gap between rich and poor among different population strata and different regions within the country (Ministry of Planning and Investment 2002). In 1993, 58 percent of the population were regarded as "poor". Five years later, however, this proportion had fallen to 37 percent. It has further declined from 29 percent (2002) to 20 percent (2004) (Gutman et al. 2006). Although achievements in poverty reduction have been considerable, there are still a large number of people who are vulnerable to crises, which could push them back into poverty (Beckman 2001). At present, many households continue to face difficulties to escape poverty due to the reasons of lack of access to markets, employment and education opportunities, poor health, difficult living environment, polluted environment, and lack of information and participation (Ministry of Planning and Investment 2002). Many international organizations such as UNDP, World Bank and DIFD (The Department for International Development, United Kingdom) as well as some NGOs which had participated in a joint project for poverty reduction in Vietnam, argued that the main characteristics of the poor in Vietnam are; i) they are farmers, ii) they have relatively low levels of education attainment, iii) they have less access to material resources such as land, iv) less access to social and physical infrastructure (World Bank 1999), which are also commonly found in many developing countries.

In a detailed report on the poverty and problems of rural areas in Vietnam, the Japan Bank for International Cooperation issued an overview of the state of poverty: "They are poor because of shortage of off-farm job opportunities, less developed state of rural infrastructure, widening income disparities among regions and among different income classes" (Japan Bank for International Cooperation 2003). The poor in the rural area tend to engage mainly in agriculture or have unstable jobs. They generally have low level education and limited professional and business skills (Centre for International Economics, Canberra and Sydney 2002). In the research of Malin Beckman (2001), factors of poverty in the central areas and lowland delta were identified as less access to land, health problems, small amount of labour in relation to dependants in the family and negative debt spirals caused by taking private loans to solve immediate crises such as sickness. Although these researches have offered a broad description of poverty and the reduction policies in Vietnam, through the macro scale analysis, these researches do not enlighten us to the "real" poverty situation on a micro scale of communes. Despite being in the same socioeconomic settings, people of differing livelihoods often behave differently when facing poverty. This can be clarified by micro scale fieldwork investigating the livelihood of households.

Some researches such as Truong and Brzeski (1998) and Nguyen (2002) have tried to grapple with the changes of residents' livelihood in Tam Giang Lagoon. However, those researches were conducted before 2000, after which shrimp aquaculture was widely introduced to the area, so they focused on the process of water surface allocation and were not able to clarify the livelihood changes and consequent internal disparities among the local people.

In order to compensate for the flaws described above, the authors carried out a livelihood survey in Phu An Commune on the shore of the Tam Giang Lagoon, one of the largest lagoons in Asia, during the period of March and September in 2006. The areas surrounding Tam Giang Lagoon have experienced dramatic changes during the last 20 years in part due to the globalization of seafood products and have become one of the major sources of raised shrimp in the world market.

In this paper, the authors attempt to clarify the characteristics of the "poor" households in Phu An Commune, which are defined by the Vietnamese Government, breaking down the residents' livelihood into five categories, namely mobile gear fishing, fixed gear fishing, farming, farming and fishing, and service. Insight into the detailed situation of the "poor" households in the area will be given through the comparison of the "poor" and the non-"poor" within the categories. This in turn gives us a clue to expound "Who are the winners and losers?" in the process of the "Doi Moi" policy and the introduction of shrimp aquaculture in the areas of Tam Giang Lagoon, Central Vietnam.

To understand the socioeconomic background of poverty in the area, the authors firstly examine the changes in agriculture as well as shrimp aquaculture. Next, the constraints which make it difficult for the majority of locals to escape from poverty are discussed. Then, the perceptual changes in the poverty situation by 


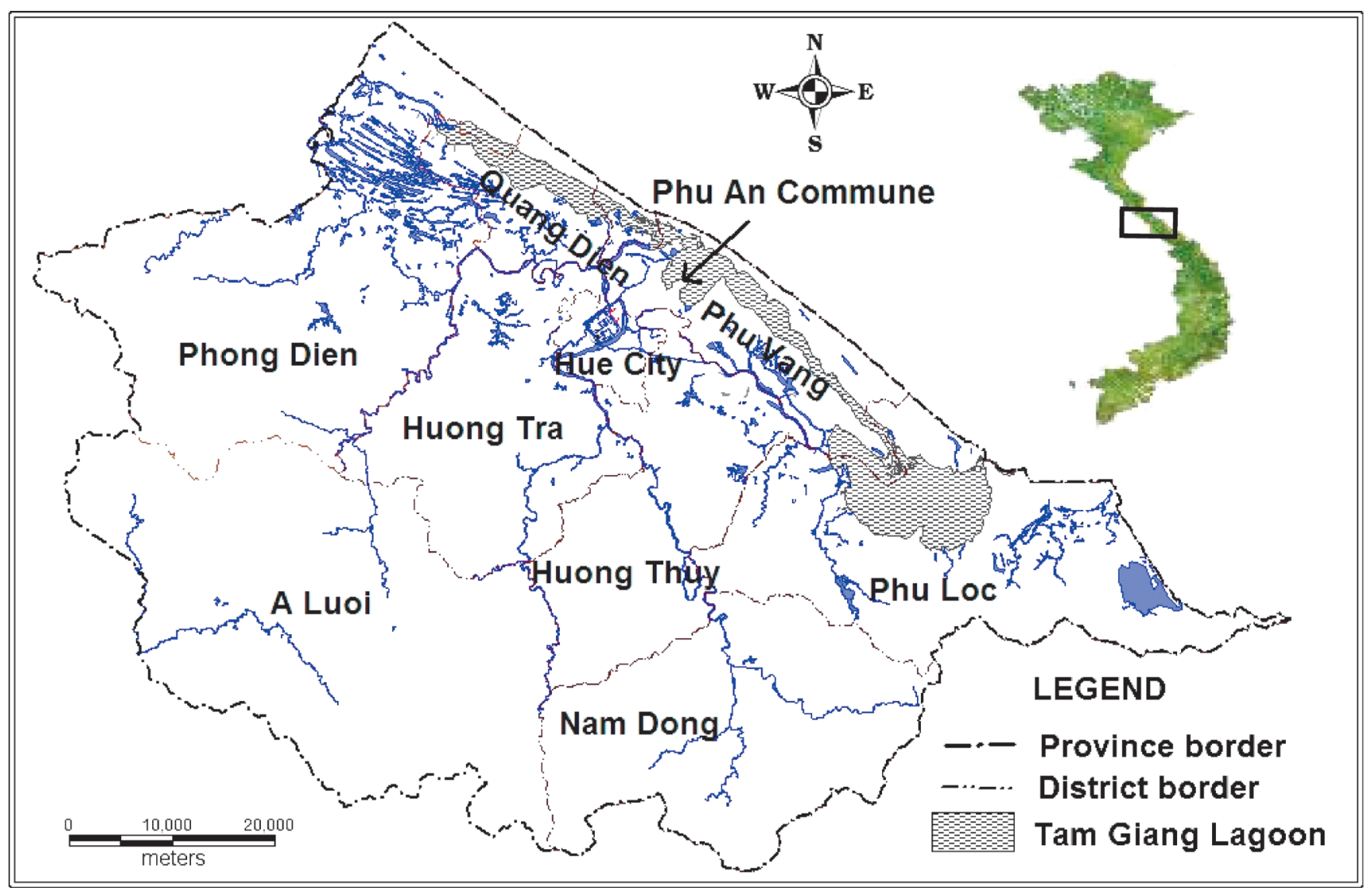

Figure 1. Location map of the study area; arrow indicates Phu An Commune

Source: Faculty of Land Resources and Agricultural Environment, Hue University of Agriculture and Forestry, Vietnam, 2006 (modified by the authors).

the locals for the last 20 years will be also discussed. Based on the above analyses, the vicious circle of the poverty in the Tam Giang Lagoon area will be elucidated.

Though the operational definition of the "poor" by the Vietnamese government adopts income as a single indicator, it can be a milestone to accomplish the objects of this research, because this research does not aims to propose a theoretical definition on poverty, nor to establish a poverty indicator system, but to show the reality of the "poor" in the area of Tam Giang Lagoon, which has been included in the global food market, whether intentionally or not.

\section{Outlines of Phu An Commune and Tam Giang Lagoon}

\section{Physical conditions of Phu An Commune and Tam Giang Lagoon}

Phu An Commune is one of 21 communes and towns of Phu Vang District, Thua Thien Hue Province, Central Vietnam. It is located on the shore of Tam Giang Lagoon, one of the biggest lagoons in Asia whose area is about 22,000 hectares with a length of $70 \mathrm{~km}$ along the coast
(Figure 1).

The total area of Phu An Commune is 1,128 hectares and over 500 hectares are occupied by Tam Giang Lagoon, which is utilized for fishing and traffic (Figure 2). Community settlements exploit the lagoon's resources such as fishes, shrimps, shellfish, edible seaweeds and farm on the sandy land at its edge. The area used for food production is 269 hectares, of which 220 hectares are planted spring paddy crop and 49 hectares for summer paddy crop. ${ }^{1}$

High temperatures are recorded normally in June, July and August, while low temperatures in November, December and January. The high temperatures in the former three months bring many difficulties to agricultural and aquacultural production. During the three months, the shortage of fresh water for daily use and water supply for agricultural and aquacultural activities is quite a serious problem in the area around Tam Giang Lagoon. Every year, the northeast wind, approximately from October to December, causes rain and cold weather. The rainfall in this area is ranked as one of the high levels in the country. The annual average rainfall is $3,200 \mathrm{~mm}$. The highest rainfall is usually found in October while the 


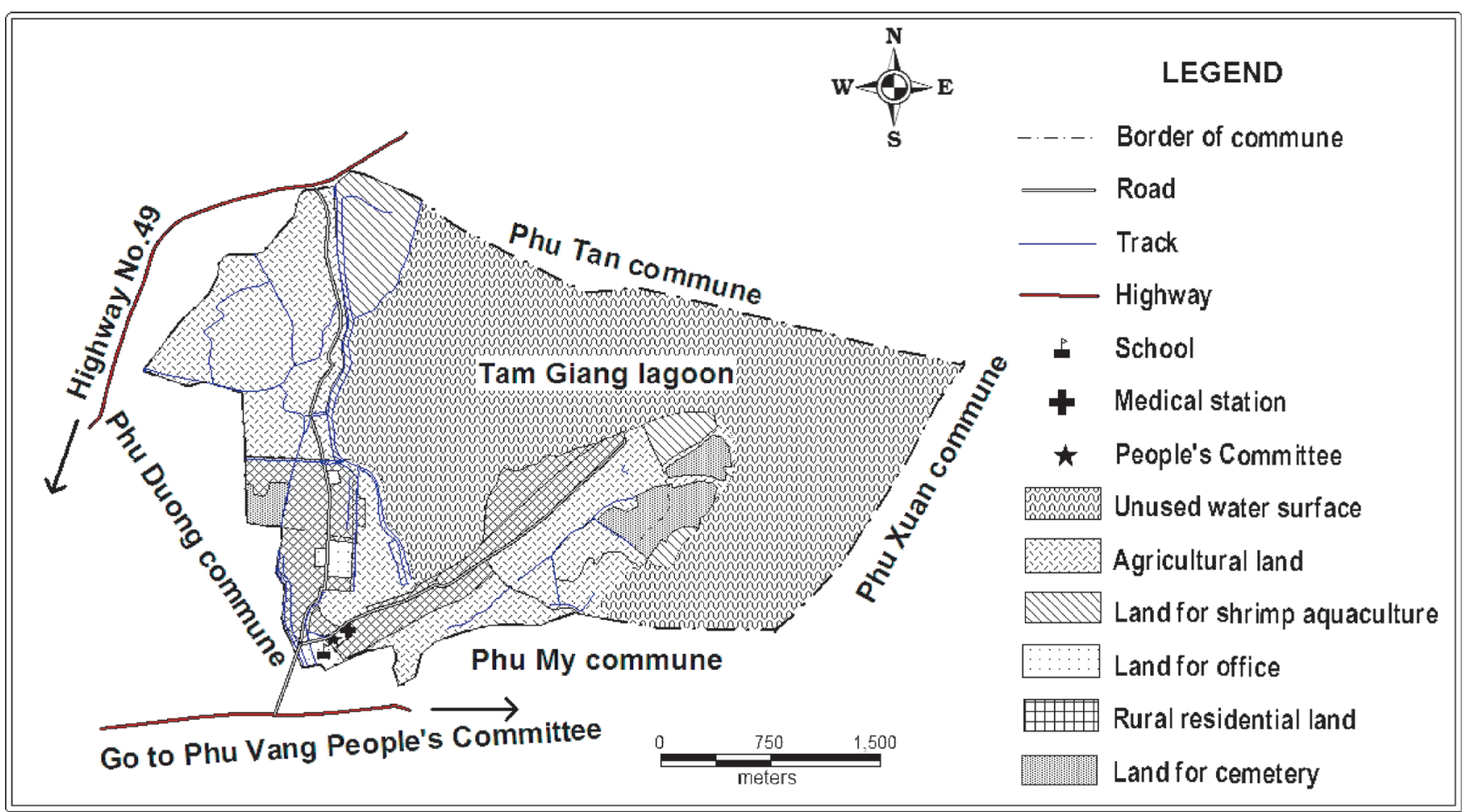

Figure 2. Land use map of Phu An Commune, 2006

Source: Faculty of Land Resources and Agricultural Environment, Hue University of Agriculture and Forestry, Vietnam, 2006 (modified by the authors).

lowest rainfall is in February (Phu An People's Committee 2004). Due to the high rainfall in a short time as well as its location in the estuary of two rivers, the area around Tam Giang Lagoon is prone to inundation. It often does damage to the residents and their produce as well.

\section{Socioeconomic situation of Phu An Commune}

Administratively, Phu An Commune is divided into four villages. The population is 8,749 persons with 1,583 households as of 2006. About 82 percent of households are involved in agriculture and/or aquaculture, 13 percent in only fishing including net-enclosure ${ }^{2}$ and five percent in services such as distilling rice liquor, woodworkers, barbers and retailers. The proportion of households who use electricity is about 95 percent. The proportion of households who use tap water for daily use is 85 percent. The rest use water from ponds, wells and/or the lagoon. The average income per capita per year is about 327 USD (Phu An People's Committee 2005). Despite their diversified occupations, the residents in Phu An Commune can be categorized into five groups based on their livelihood (Table 1).

\section{Changes in Agriculture and Aquaculture in Phu An Commune}

\section{Changes in agriculture}

After the unification of Vietnam in 1975, local resources were managed by a cooperative called "hop tac xa" in Vietnamese. Lands belonged to a cooperative which designed and carried out production plans. Phu An Commune was not exceptional. Most agricultural lands were used for growing local rice varieties and sweet potato with low yields in the area (Phu An People's Committee 2005). In 1993, the lands were allocated to households for long term use of 20 years in accordance with the Land Law. The remaining lands, such as non-cultivated lands, degraded lands and abandoned lands, were legally under the control of the local government. However, most of the allocated lands were used only for rice cropping, with up to two harvests now available each year. Both in spring and summer seasons, farmers faced problems with water shortage and pest infestation leading to low yields of rice. The changes in land use from 1999 to 2005 are indicated in the Table 2.

Table 2 shows that the acreage of agricultural lands decreased from 265 hectares to 223 hectares (approximately 42 hectares) during the period of 1999 to 2005. Those lands were mainly converted to earth ponds ${ }^{3}$ 
Table 1. The occupational classification of resident groups of Phu An Commune

\begin{tabular}{|c|c|c|c|}
\hline Category & Characteristics & $\begin{array}{l}\text { Number of } \\
\text { household* }\end{array}$ & $\begin{array}{c}\text { Percentage } \\
(\%)\end{array}$ \\
\hline Mobile gear fishing & $\begin{array}{l}\text { This group is usually called the "Sampan people". They are a fishing group who can only afford } \\
\text { simple fishing gear such as eel rakes, push-nets, clam rakes, gill-nets, and drag-nets. They also } \\
\text { collect clams by hand. In this group, } 15 \text { households are living on boats around the lagoon, } \\
\text { without land even for housing. The rest was settled on land in the commune. They have not } \\
\text { been allocated fishing grounds and can fish anywhere on the lagoon. They live separately } \\
\text { from the other groups and the education level is low. Thus, it is difficult for them to discuss } \\
\text { the threats of aquatic resource depletion, and the local government's regulations on resource } \\
\text { protection, by participating in meetings. }\end{array}$ & 105 & 7.0 \\
\hline Fixed gear fishing & $\begin{array}{l}\text { This group consists of } 107 \text { households who have acquired rights, mainly through inheritance, } \\
\text { to use fixed gear fishing in the grounds, in accordance with the laws of the feudal government } \\
\text { and local customs, maintained by the present government. They are highly skilled at } \\
\text { fishing. Their fishing grounds are located in areas which have a variety of fish, crustaceans } \\
\text { and mollusca. They usually use net enclosures as tools in aquaculture. The difficulties that } \\
\text { they have faced include lack of capital and aquaculture techniques. Moreover, the failure in } \\
\text { aquaculture through disease, has led to large debts with bank and lenders which is a great } \\
\text { threat for this group. }\end{array}$ & 107 & 7.0 \\
\hline Farming & $\begin{array}{l}\text { The main occupation of this group is agriculture. The households of this group have } \\
\text { advantages accrued through participation in the economic development programs of the } \\
\text { local government. They can depend on themselves and improve their own living conditions. } \\
\text { They have access to credit schemes and other non-agricultural production activities. However, } \\
\text { they still need more support in obtaining market information, capital, and new techniques } \\
\text { to change their production schemes from rice monoculture to pluri-activities to help them } \\
\text { escape poverty. }\end{array}$ & 563 & 35.0 \\
\hline Farming-Fishing & $\begin{array}{l}\text { The main occupation of this group is not only agriculture but also fishing on the lagoon } \\
\text { during the agricultural off season. Since 1999, they have been active in aquacultural } \\
\text { development in the lagoon under the development strategies of Thua Thien Hue Province. } \\
\text { It has been a great opportunity for them to increase their income, as well as creating more } \\
\text { jobs. This group is however, susceptible to the disadvantages associated with agricultural } \\
\text { production, fishing and aquaculture, such as flood, drought, saline intrusion, pestilent insect } \\
\text { and shrimp disease. }\end{array}$ & 728 & 46.0 \\
\hline Service & $\begin{array}{l}\text { This group is usually shopkeepers, woodworkers, barbers and retailers. Some people purchase } \\
\text { aquaculture products around the commune and then transfer to another place for re-selling. } \\
\text { On the whole, this group has the ability to get enough income for their daily consumption } \\
\text { but few or no savings, particularly in the households of widows, the chronically diseased and } \\
\text { the elderly. The disadvantages of this group are lack of capital, market information and output } \\
\text { market, as well as of skills in business and production. }\end{array}$ & 80 & 5.0 \\
\hline
\end{tabular}

* Synthesized data from Phu An People's Committee, 2006.

Source: Authors'survey, 2006.

for aquaculture and irrigation channels. Additionally, the water surface area for fishing also decreased because the local government opened many waterways for traffic and it took away parts of the water surface area during these periods, even though the newly constructed earth ponds were added to the water surface area.

Crop diversification has had a positive effect on agricultural production as well as exploiting the aquatic resources in the lagoon. This method was adopted by local people (Figure 3). Before 2000, the farmers only grew a single crop of rice per year. During the off-season, the farmers also fished in the lagoon by using a simple instrument such as a gill net, a dragnet, a push-net or an
Table 2. Changes in land use from 1999 to 2005 in Phu An Commune (Unit: hectare)

\begin{tabular}{|l|r|r|r|r|}
\hline \multicolumn{1}{|c|}{ Use types } & 1999 & 2000 & 2003 & 2005 \\
\hline $\begin{array}{l}\text { Land for single crop } \\
\text { rice }\end{array}$ & 265.24 & 233.84 & 229.84 & 158.46 \\
\hline $\begin{array}{l}\text { Land for double } \\
\text { crop rice }\end{array}$ & - & - & - & 65.00 \\
\hline $\begin{array}{l}\text { Water surface area } \\
\text { for fishing }\end{array}$ & 229.91 & 214.00 & 224.52 & 212.31 \\
\hline
\end{tabular}

Source: Phu An People's Committee, 2006. 
eel-net. After 2000, under the "Doi Moi" policy, due to which individuals can now buy and sell produce privately, farmers were encouraged to diversify their products with new crops especially in low yield rice fields. Farmers plant varieties of crops during spring and summer seasons, which keep them busy with farming for five to six months per year.

\section{Changes in aquaculture}

As indicated in Figure 3, before 1999, there were no families to raise shrimp or fish in the earth ponds in Phu An Commune. Under the aquacultural development in the early 2000s, the local people have broken up the aquacultural harvest into two seasons (spring and summer) and they have adopted a fixed calendar to raise shrimp, fish and other aquatic resources on their own initiative. Some residents submitted a petition to the local government, asking to convert their fishing corral grounds into aquaculture surfaces such as earth ponds and netenclosures. Because each fishing ground was large, covering from two hectares to more than five hectares, the local government restricted the acreage of an earth pond and a net-enclosure to 1.5 hectares per household. ${ }^{4}$ After receiving the licenses from the local government, the fishers set nets along the boundary of their fishing corral grounds. In the regulations, aquaculture had to be started within one year after the date of license issue and the area should be surrounded by an earth dike ${ }^{5}$ (Figure 4), otherwise the licenses would be revoked. But in reality, due to lack of capital for investing in a dike and lack of knowledge on aquaculture techniques, the fishers have continued to culture by using single nets. ${ }^{6}$ Net-enclosures have developed into a system of pluri-nets ${ }^{7}$ (Figure 5). Within the main nets surrounding the entire area, a smaller area was enclosed with nets of finer mesh size for raising shrimp and fish. The outside of the small culture area was devoted to corral fishing.

Table 3 shows that earth ponds became extremely popular between 2000 to 2003, and the acreage increased from 38.6 hectares to 88.52 hectares. The high price of shrimp on the world's market and the great income from aquaculture had been encouraging the fishers to enlarge the acreage. However, after some initial success, aquatic disease and epidemics, resulting from poor water quality, presented a serious constraint to the development of sustainable aquaculture in Phu An Commune and in the whole of the Tam Giang Lagoon.

Table 3 also indicates the changes in the acreage, number of aquaculture households and numbers of aquaculture teams during the period of 1999-2005. The number of households and aquaculture teams which had participated in aquaculture activities increased until 2000 and 2003, respectively. Then, they decreased during the period of 2003-2005. The reason for the decrease both

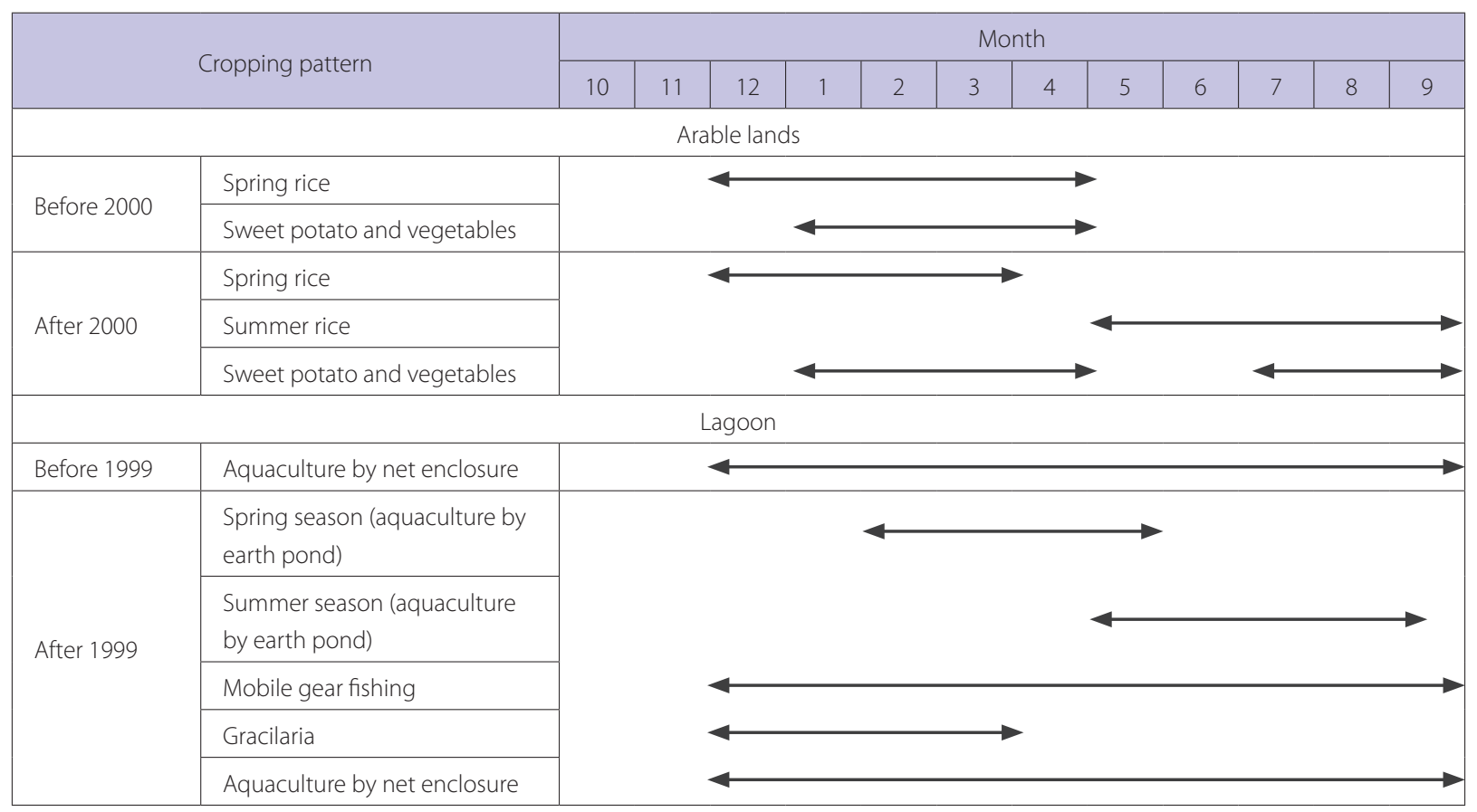

Figure 3. Calendar showing livelihood activities of farmers and fishers in Phu An Commune Note: The people in Phu An Commune still use a traditional calendar: Spring (February-April); Summer (May-July); Autumn (August-October); Winter (November-January). Source: Authors'survey, 2006. 


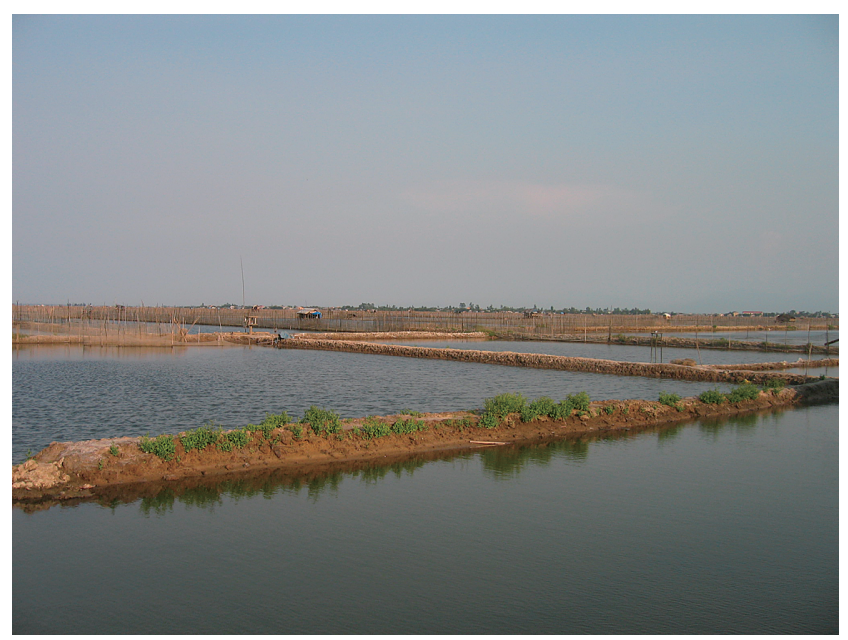

Figure 4. Aquaculture by earth pond Photo by the authors, 2006

in the number of households and the acreage for shrimp aquaculture during the periods can be explained by some of them not being able to invest additional money to continue shrimp aquaculture. The decrease in their revenues due to serious disease during these periods made them unable to cover the costs for feeding and prevention of disease. Moreover, the high pressure from loan interest for the initial investment pushed them to abandon shrimp aquaculture. The acreage of the netenclosure aquaculture also decreased because the local government revised the plan for the water surface use of 200 hectares and it withdrew a part of each net-enclosure surface in order to open new waterways.

Additionally, the process of privatization of the fishing ground began around the year of 2003. Community property rights have been changed to family or group ownership, and this led to the curtailment of the water surface area in the lagoon where the "Sampan people" catch aquatic resources as their daily livelihood. The exclusion of the "Sampan people" occurred in the traditional fishing grounds. As a result, they face many difficulties in sustaining their daily lives.

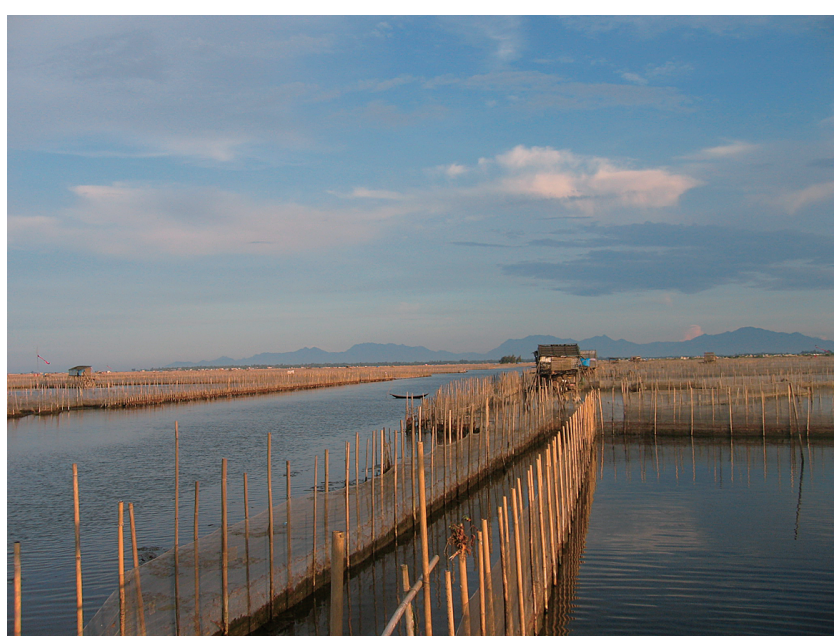

Figure 5. Aquaculture by net enclosure Photo by the authors, 2006.

\section{Methodology and Sampling of the Surveyed Households}

In order to clarify the characteristics of the "poor" households in the Tam Giang area, the authors carried out an investigation utilizing questionnaires, in-depth interviews and participatory observation. In total, 60 households were sampled in relation to their livelihood. Initially, 24 households were chosen based on the list of "poor" households, produced by the authority of Phu An Commune in $2005^{8}$. The final 35 households were randomly chosen in relation to their livelihood.

The general process of listing the "poor" households in Vietnam is as follows: the head of the hamlet organizes a meeting with the representative of each household. Based on subsequent discussion and voting, certain households are recommended as candidates to the People's Committee of Commune. The Committee assesses the listed households via an interview regarding the total income of each household in the previous year. If the monthly income per capita of a household is under 200,000 VND, the household will be recorded in the list of the "poor" households of a commune. During this process, the criterion used by the Vietnamese Government oftentimes

Table 3. Situation of aquaculture during the 1999-2005 period

\begin{tabular}{|l|l|c|c|c|c|}
\hline \multirow{2}{*}{} & \multirow{2}{*}{ Unit } & \multicolumn{4}{|c|}{ Year } \\
\cline { 3 - 6 } & & 1999 & 2000 & 2003 & 2005 \\
\hline Earth pond area & Hectare & 3.00 & 38.60 & 88.52 & 84.00 \\
\hline Net enclosure area & Hectare & 226.91 & 175.40 & 136.00 & 128.31 \\
\hline No. of aquaculture household & Household & 198 & 212 & 206 & 203 \\
\hline No. of aquaculture team & Team & 6 & 7 & 8 & 3 \\
\hline
\end{tabular}

Source: Authors'survey, 2006 
fluctuates. This means that in some cases, households whose monthly income per capita is under 200,000 VND may be omitted in the list, while in others, households whose monthly income per capita is over 200,000VND may be included.

In this study, 16 households out of the 59 analyzed have been misclassified in terms of poverty status. Among them, eight "poor" households were classified as non"poor" by the People's Committee and another eight non-"poor" households were classified as "poor". It may be argued that some of them may have changed their poverty status over the last year, but in reality this occurs very rarely. The next chapter will be devoted to detailed discussion of the multi-dimensions of poverty and its diversification in the Tam Giang area.

\section{Main Characteristics of the "Poor" Households}

There are several socioeconomic characteristics which are closely related to poverty; they can either influence the level of welfare of households, or they are a direct consequence of the poverty. Traditionally, poverty is defined in terms of some measure of monetary income considered adequate for subsistence. However, income in monetary terms may not be an adequate measurement of living conditions for poor populations (Naseem 1999). In other words, poverty is a multi-dimensional problem and its characteristics are interrelated. In the scope of this research the authors discuss several main characteristics of the poor in the Phu An Commune. These were identified through interviews with the villagers based on their livelihoods, and are divided into the following subcategories: income, expenditure, labour force, educational approach and land assets.

\section{Income}

In order to understand the livelihood of local residents, the authors carried out a survey on income based on the catalogues of selling rice and vegetables, chickens, ducks, pigs, fishes and shrimps, income from off-farm activities, and the money received from migrant workers or charity organizations. The results of the numbers of the "poor" households and the average households' incomes, broken down into their livelihoods, are shown in Tables 4 and 5.

Table 4 reveals differences between the "poor" and the non-"poor" households in terms of income. Inhabitants of the "poor" households tend to derive their income through "Mobile gear fishing" (these are the "Sampan people") and "Farming". Approximately 75\% of the "poor"
Table 4. Number of "poor" households broken down into residents' livelihoods (Unit: household)

\begin{tabular}{|l|r|r|}
\hline \multicolumn{1}{|c|}{ Occupation } & "Poor" group & Non-"poor" group \\
\hline Mobile gear fishing & 11 & 4 \\
\hline Fixed gear fishing & 2 & 9 \\
\hline Farming & 7 & 4 \\
\hline Farming-Fishing & 1 & 10 \\
\hline Service & 3 & 8 \\
\hline Total & 24 & 35 \\
\hline
\end{tabular}

Source: Authors'survey, 2006.

Table 5. Average monthly income per capita of the "poor" and the non-"poor" household (Unit: $1000 \mathrm{VND})$

\begin{tabular}{|l|r|r|r|}
\hline \multicolumn{1}{|c|}{ Occupation } & \multicolumn{1}{c|}{$\begin{array}{c}\text { "Poor" } \\
\text { household }(\mathrm{A})\end{array}$} & $\begin{array}{r}\text { Non-"poor" } \\
\text { household (B) }\end{array}$ & A/B (\%) \\
\hline Mobile gear fishing & 132,666 & 327,084 & 41 \\
\hline Fixed gear fishing & 128,334 & 389,797 & 33 \\
\hline Farming & 119,143 & 324,554 & 37 \\
\hline Farming-Fishing & 151,042 & 476,180 & 32 \\
\hline Service & 161,548 & 275,521 & 59 \\
\hline
\end{tabular}

Source: Authors'survey, 2006.

households are engaged in these livelihoods, which were left behind as a result of the "Doi Moi" policy. On the other hand, approximately 54\% of the non-"poor" households rely on farming-fishing and fixed gear fishing, both of which have been greatly affected by the "Doi Moi" policy, and also the global food market.

Table 5 shows that the greatest difference in average income between the "poor" and the non-"poor" households within the same occupational groups is found in the farming-fishing and fixed gear fishing group, while the smallest is found in the service and the mobile gear fishing group. This implies that shrimp aquaculture is a high risk occupation, but it has also brought great opportunity to the local people. Conversely, the non"poor" households in the service and mobile gear fishing groups differ little from those of the "poor" households, and are prone to be "poor". If the unusual case from the mobile gear fishing group (Case 2 below) whose monthly income per capita is extraordinarily high is excluded, the average income of the non-"poor" mobile gear fishing group decreases to $256,945 \mathrm{VND}$, and the ratio between the "poor" and the non-"poor" becomes 52\%.

To summarize, the "Doi Moi" policy and the subsequent changes in agriculture and aquaculture in the Tam Giang area, have brought opportunities to some of the local people, whilst leaving the majority behind 
these rapid socioeconomic changes. This has resulted in increasing social disparity.

Some of the data in Table 5 should be carefully interpreted. Although the average monthly income of the poor fixed gear fishing group is lower than those of the mobile gear fishing, the meaning of this statistic is limited due to its small number of sampled households. In order to allow for the limitations of the statistical analyses, the authors also conducted in-depth interviews as follows:

Case 1: Mr. Van belongs to the mobile gear fishing group. His family has seven members, of which five persons are at working age. Before 2000, his family had lived on the boat in Tam Giang Lagoon. The resettlement program of the Vietnamese Government provided a chance for his family to move on land. At the time of our survey, his family was living in temporary housing with an area of $50 \mathrm{~m}^{2}$. Each day, he and other members of his family would go to the lagoon to catch fish and shrimp as well as other marine resources. Due to lack of space for fisheries and a decline in the aquatic resources of the lagoon, in spite of a substantial number of workers, the family's income from fish and shrimp is only 20,000 VND/ day during the fishery season. However, this catching activity ceases from the end of October to the end of December due to bad weather. In early 2006, he borrowed 5,000,000 VND from the Fund for Poverty Reduction for buying fishing gear and was unable to pay this back at the time of our survey. His family's total income is calculated at roughly $13,000,000$ VND per year. The average monthly income per capita for his family is under 200,000 VND however his family has not been listed on the "poor" households of Phu An Commune.

Case 2: Mrs. Nguyen belongs to the mobile gear fishing group. Her family has two members. Each day, she goes to the Tam Giang Lagoon to catch fish and shrimp by herself. Her son is working in Hue City and receives salary monthly. At the time of our survey, she borrowed 3,000,000 VND from her relatives to buy fishing gear and furniture, but had paid back all her lenders. Her family income is calculated about $12,900,000$ VND per year due mostly to her son's salary. Because there are few members in her family, and she receives a stable salary from her son, the average income of her family is higher than most other households and the Vietnamese Government's criteria for a non-"poor" household. However, her family was recorded in the list of the "poor" households of Phu An Commune.

Case 3: Mr. Phan who belongs to the fixed gear fishing group, is living in temporary housing with an area of $35 \mathrm{~m}^{2}$. His family has four members of which two are at working age. Mr. Phan owns $1,000 \mathrm{~m}^{2}$ of the water surface of lagoon for raising fishes and shrimps. In his spare time, Mr. Phan sometimes works as a bricklayer in order to earn additional income. At the time of our survey, Mr. Phan had not borrowed any loans from the banks. Our analysis indicates that the total income of his family is approximately $17,000,000 \mathrm{VND}$ per year. The average monthly income per capita of his family is over 200,000 VND, but his family has been listed on the "poor" households of Phu An Commune.

Case 4: Mr. Doan belongs to the farming group. His family has eight members but only two are able to work. The eldest daughter has ceased attending school and works as an "Oshin"9 in the commune although she is only 15 years old. The family's livelihood depends on only $2,300 \mathrm{~m}^{2}$ of agricultural land which is a rice monoculture. At the time of our survey, he had borrowed 1,000,000 VND from the Fund for Poverty Reduction for buying fertilizers and for daily expenses. Our analysis indicates that his total family income is approximately $6,600,000$ VND per year. As his livelihood depends on rice monoculture, and there are many family members, their average monthly income per capita is only $68,750 \mathrm{VND}$ which is too low to support themselves, over their average monthly expenditure per capita (83,229 VND). His family is one of the "poor" households in the list of Phu An Commune.

The case study especially of income levels shows that the local residents who belong to the groups of mobile gear fishing and farming, seem to be the "losers" following the implementation of the "Doi Moi" policy and aquacultural development around the Tam Giang Lagoon. This is due to:

i) lack of space for fisheries and the decline of aquatic resources in the lagoon as a result of both legal and illegal over-exploitation,

ii) the fact that their lives depend mainly on natural resources which are often affected by uncertain weather conditions and fluctuating market prices,

iii) the monoculture of rice,

iv) small areas of agricultural land for production, and

v) many dependent members within a household.

The characteristics mentioned above, in conjunction with population growth and the frequent separation of households in the area, increase the number of households which engage in catching fish and shrimp. As a result, individuals belonging to the mobile gear fishing and the farming groups are facing increasing competition for decreasing natural resources in the lagoon. 
Table 6. Average monthly expenditure per capita of the "poor" and the non-"poor" household (Unit: 1000 VND)

\begin{tabular}{|l|r|r|r|}
\hline \multicolumn{1}{|c|}{ Occupation } & \multicolumn{1}{c|}{$\begin{array}{c}\text { "Poor" } \\
\text { household (A) }\end{array}$} & $\begin{array}{c}\text { Non-"poor" } \\
\text { household (B) }\end{array}$ & A/B (\%) \\
\hline Mobile gear fishing & 200,099 & 235,624 & 85 \\
\hline Fixed gear fishing & 220,892 & 333,723 & 66 \\
\hline Farming & 143,428 & 308,141 & 47 \\
\hline Farming-Fishing & 186,719 & 437,209 & 43 \\
\hline Service & 188,170 & 281,582 & 67 \\
\hline
\end{tabular}

Source: Authors'survey, 2006.

\section{Expenditure}

Poverty can also be expressed in relation to the expenditure capacity of households. The authors carried out a survey of expenditure with the catalogues of buying food and daily use, tuition, membership fees for various associations, consumption during holidays such as the Lunar New Year, First Full Moon Festival and Praying for Fish Festival, agricultural tax, and capital for investing in crop production and livestock breeding such as seeds, chemical fertilizers, pesticides, herbicides, feed, livestock breeds, farming and fishing tools.

The information gathered from the survey indicates that the greatest proportion of a households expenditure is used towards daily meals, feed for shrimp and fish, buying tools for agricultural and aquacultural activities, and school fees for their children. The results shown in Table 6 indicate that most of the "poor" households had expenditure greater than their income. This is particularly true for "poor" members of the mobile gear fishing group. This can be explained by the fact that these households are living on the lagoon, and thus a boat is their home. Each year, they must repair their boats, or even buy new ones. This is one explanation for why their expenditure is so high. In addition, there are often many members in these households. Therefore, their daily needs such as eating, drinking, clothing, and transportation are also higher. As a result, their expenditure always exceeds their income.

For other groups, reasons for the gap between income and expenditure are as follows:

i) Besides daily expenditures, the surveyed households had to attend to ceremonial activities such as funerals, worship of ancestors, and wedding events. These activities form a considerable part of their expenditure.

ii) Some households have family members with serious illnesses or chronic diseases. They have to spend a large amount of money on treatment. An example was given through an in-depth interview with Mr. Tran: Mr. Tran belongs to the fixed gear fishing group and is living in temporary housing with an area of $55 \mathrm{~m}^{2}$. His family has five members including his father and mother, who are 85 and 77 year olds respectively. He owns 1,000 $\mathrm{m}^{2}$ of water surface in the lagoon for aquaculture. Since he has not enough capital to raise shrimp and fish with high individual density, his income derived from selling products from the lagoon is low. The survey indicates that his family income is approximately 6,400,000 VND per year, while the expenditure is approximately $15,565,000$ VND per year. Prior to our survey, his mother had been ill and had stayed in the hospital for one month; therefore, he had to pay many additional expenses, for example hospital fees, transportation fees, and costs of medicine. As a result, the expenditure of his family was double that of his. At the time of our survey, he still owed $1,300,000$ VND to the banks.

iii) In recent years, in order to develop aquaculture in the area, "poor" households belonging to the fixed gear fishing and farming-fishing groups, have invested increasing amounts of money and labor into aquaculture activities such as building earth ponds, surrounding netenclosures, buying hybrid shrimps and fishes, and buying feed for shrimp and fish. In spite of failures in aquaculture due to epidemics of fish or shrimp, and the fluctuation of prices caused by a lack of market information, these households still spent money on farming and aquaculture activities in an attempt to recover a part of their invested capital. Due to shortages of capital, they often had to borrow money from banks or private money lenders and pay interest monthly. As a result, their expenses become higher.

iv) Often couples have many children, especially of school age. Mr. Doan's household is an example of this: Mr. Doan belongs to the farming-fishing group. His family has eight members with five children of school age. $\mathrm{He}$ and his wife are cultivating rice on $4,000 \mathrm{~m}^{2}$ of agricultural land and catch fish and shrimp in Tam Giang Lagoon over an area of water covering one hectare. Our survey indicates that the total of his family income is approximately $14,500,000 \mathrm{VND}$ per year, while expenditure is roughly $17,925,000 \mathrm{VND}$ per year. At the time of our survey, he still owed 5,000,000 VND to the bank. Besides the capital needed for investment in agricultural production and fishing such as buying seeds, fertilizers and nets, he had to spend a large amount of money on his five children, for example for tuitions, buying uniforms and text books. This made his livelihood considerably more difficult. 


\section{Labor force}

In developed areas where mechanization has been implemented, the labor force may not be a crucial component of production. However, it is still a vital factor for the poor in underdeveloped areas such as Phu An Commune. Of the 59 surveyed households, the "poor" households often have five or six members, or even eight or nine. Often however, there are only two or three members who are considered as major labor forces. There are various circumstances that can lead to this situation:

i) Households which have family members with serious illness or chronic diseases must divide their time between working and caring for the patient, which reduces their earnings. In addition, these families had to spend extra money on treatment.

ii) Families with many children are particularly poor as their children are still small and cannot work as part of the labor force.

iii) Divorce or the death of a spouse also contributes to the loss of part of the labor force or limits capacity which can drive households into poverty.

According to our survey, a new phenomenon has recently been witnessed in the commune. The local people have started to migrate to urban areas to seek offfarm jobs, because of lack of job opportunities and low wages in and around the commune. In total, of the 59 surveyed households, there were 43 persons across both the "poor" and the non-"poor" groups, who intended to go to cities to find jobs such as "Oshin", or hired housework for between 6 months and a year. The offfarm employment could be a chance for the local people to escape from poverty. However in Phu An Commune, such opportunities are unavailable as the "poor" are the least qualified and have insufficient money to cover the migration costs.

\section{Educational approach}

According to officials in Phu An Commune, the educational situation has been improved rapidly through an increase in the number of primary schools, classrooms and teachers. As a result, the number of children attending primary and secondary schools has also significantly increased. Many villagers have learned that no education will lead to poverty. However, there has been little change in the proportion of highly educated individuals.

Table 7 shows that lack of advanced education is one of the biggest problems of the "poor". Heads of households who graduated from secondary school and high school are rare in the "poor" group. In addition, the heads of mobile gear fishing households are often illiterate. Low education is one of the obstacles for the "poor" households because they do not have the knowledge to approach new techniques and skills in shrimp aquaculture, nor to adapt to the market system. Some households can only sell their products through middlemen generating low prices, since they have limited understanding of marketing systems. In Phu An Commune, there is no large-scale commercial association to mediate profitable interactions between the producers and their market.

Currently, it is still very difficult for the poor to support their children's schooling. Many children have to stop going to school due to many reasons arising from poverty. Through our interviews with the villagers and the officials, the reasons for leaving school have been identified as follows:

i) due to the difficult economic situation, families

Table 7. Educational attainment of heads of households broken down into residents' livelihoods (Unit: person)

\begin{tabular}{|c|c|c|c|c|c|}
\hline \multirow{2}{*}{\multicolumn{2}{|c|}{ Occupation }} & \multicolumn{4}{|c|}{ Level } \\
\hline & & \multirow{2}{*}{$\begin{array}{l}\text { Illiteracy } \\
5\end{array}$} & \multirow{2}{*}{$\begin{array}{r}\text { Primary school } \\
6\end{array}$} & \multirow{2}{*}{$\begin{array}{r}\text { Secondary school } \\
0\end{array}$} & \multirow{2}{*}{$\begin{array}{l}\text { High school } \\
0\end{array}$} \\
\hline \multirow{5}{*}{ Poor group } & Mobile gear fishing & & & & \\
\hline & Fixed gear fishing & 0 & 2 & 0 & 0 \\
\hline & Farming & 1 & 4 & 1 & 1 \\
\hline & Farming-Fishing & 1 & 0 & 0 & 0 \\
\hline & Service & 0 & 2 & 1 & 0 \\
\hline \multirow{5}{*}{$\begin{array}{l}\text { Non-poor } \\
\text { group }\end{array}$} & Mobile gear fishing & 1 & 2 & 0 & 1 \\
\hline & Fixed gear fishing & 1 & 8 & 0 & 0 \\
\hline & Farming & 0 & 1 & 2 & 1 \\
\hline & Farming-Fishing & 0 & 6 & 2 & 2 \\
\hline & Service & 0 & 5 & 3 & 0 \\
\hline
\end{tabular}

Source: Authors'survey, 2006.

Note: No person of both groups had education of university. 
cannot afford the funds for their children to go to school.

ii) instruments of study, individual tools and contributions such as school fees, funds for building school are expensive in relation to their income.

iii) the "poor" households require their children to work as part of the labor force in order to generate subsidiary earning in their hard lives.

iv) some older pupils are ashamed to go to school when they must learn alongside younger pupils.

It can be said that lack of further educational opportunities and low education levels are closely interrelated to poverty. Due to poverty, the "poor" in general, and children in particular, do not allow themselves to receive education to a sufficient level to escape from poverty.

\section{Land assets}

Legally, land in Vietnam is not owned privately by individual, but the land use rights have been allocated to them since $1993 .{ }^{10}$ The land certificates legalize the owner's rights for the long term use of allocated land, usually for 20 to 50 years depending on the type of land. Transfer, exchange, leasing, inheritance and mortgaging of the land are allowed. In Phu An Commune, agricultural land around the lagoon has been allocated to individual farming households for long term use. The remaining land, including uncultivated, degraded, abandoned or collectively used lands and lagoon areas are legally under the jurisdiction of the local Government. Our survey suggests that the lack of land for agricultural activities and lack of water surface area for aquacultural purposes in the "poor" groups, especially the "Sampan people", are serious issues that may lead to poverty in Phu An Commune.

Table 8 shows that most mobile gear fishing households in both groups have neither agricultural land nor land used for aquacultural purpose such as net-enclosure and earth pond. In addition, some mobile gear fishing households have no land for residential usage but must live on the boats. They only have part of the water surface on the lagoon as a place to catch fish, shrimp, and other aquatic resources. The farming households, however, are allocated agricultural land but the acreage is small. Therefore, it is very difficult to cover enough daily needs for supporting their family, especially when crops fail.

As mentioned in the section describing changes in aquaculture, the process of privatization of the fishing ground began in recent years. The large benefits derived from shrimp aquaculture in the early 2000s has led to encroachment of the water surface of the lagoon by some individuals in the Phu An Commune, especially households who have the economic or labor capabilities to participate in shrimp aquaculture. As a result, the common fishing ground is becoming reduced. The lives of the households which completely depend on natural resources have become increasingly unbearable. As for the newly-formed households who are living by farming activities, they are receiving less or poorer quality land because most agricultural land has already been allocated. Newly-formed households are often dependent on lands that their extended family allows them to cultivate. These lands are too small to support their consumption needs.

Table 8. Agricultural land and water surface use by surveyed households (Unit: household)

\begin{tabular}{|c|c|c|c|c|c|}
\hline \multirow{2}{*}{\multicolumn{2}{|c|}{ Occupation }} & \multicolumn{4}{|c|}{ Usage } \\
\hline & & \multirow{2}{*}{$\begin{array}{r}\text { Agricultural land } \\
0 \\
0\end{array}$} & \multirow{2}{*}{$\begin{array}{l}\text { Net-enclosure } \\
0\end{array}$} & \multirow{2}{*}{$\begin{array}{l}\text { Earth pond } \\
\qquad 0\end{array}$} & \multirow{2}{*}{$\begin{array}{l}\text { Naturally } \\
\text { catching on the } \\
\text { lagoon } \\
11\end{array}$} \\
\hline \multirow{5}{*}{ Poor group } & Mobile gear fishing & & & & \\
\hline & Fixed gear fishing & 0 & 2 & 0 & 0 \\
\hline & Farming & $6^{*}$ & 0 & 0 & 0 \\
\hline & Farming-Fishing & 1 & 1 & 0 & 0 \\
\hline & Service & 0 & 0 & 0 & 0 \\
\hline \multirow{5}{*}{$\begin{array}{l}\text { Non-poor } \\
\text { group }\end{array}$} & Mobile gear fishing & 0 & 0 & 0 & 4 \\
\hline & Fixed gear fishing & 0 & 9 & 0 & 0 \\
\hline & Farming & 4 & 0 & 0 & 0 \\
\hline & Farming-Fishing & 10 & 7 & 1 & 0 \\
\hline & Service & 0 & 0 & 0 & 0 \\
\hline
\end{tabular}

* In the poor farming's group, one household has no agricultural land. This household keeps chickens and pigs as their livelihood. Source: Authors'survey, 2006. 


\section{Perception of Poverty by Local Groups}

Under the implementation of "Doi Moi" policy during the last 20 years, the poverty reduction policy in the rural Vietnam seems to have achieved a significant result. At the same time, however, it is well known that a sense of relative poverty especially for the poor became stronger than before. In order to clarify this phenomenon, the authors conducted interviews on how the local people in Phu An Commune perceive poverty and how they evaluate their livelihood changes. The "poor" group tend to think that a "poor" household: (i) lives in a temporary house with metal roofing and without cement walls, (ii) contains sick or elderly people, a widow, or too many young children, (iii) is without capital and lacks experience in running businesses, (iv) fails in aquaculture, (v) has little agricultural land and is without water surface for aquacultural purpose, (vi) is without valuable assets such as a bicycle, television, bed and table, and (vii) has family members, who must travel to other provinces to find a job. Meanwhile, the non-"poor" group think that a "poor" household: (i) is without brick walls, (ii) has insufficient capital to run a business, plus a shortage of business experience, (iii) is without valuable assets such as a television or motorbike, (iv) contains sick or elderly people, a widow, or too many young children, (v) has a few cattle, (vi) has lost the main labour force, (vii) fails in aquaculture, (viii) is unemployed and lazy, and (ix) is poorly educated.

It seems that the local residents have a relatively accurate idea of the situation of households in the commune. Poverty herewith is not interpreted merely to be poor in income, expenditure or education; instead, even the people's own viewpoints are reasonably comprehensive. ${ }^{11}$ They did not evaluate poverty levels following the national poverty standards. Therefore, it is difficult for the "poor" to claim their rights because they do not know whether they belong to poor group according to the Vietnamese Government's classification.

Although there are still many difficulties in the residents' lives, owing to vast investment by the Vietnamese Government and international donors, the number of the "poor" households has decreased considerably (Phu An People's Committee 2005). Figure 6 shows that there were 295 families classified as "poor" households in the commune, comprising 19.8 percent of the total, in 2002. However in 2005 this had fallen to only 219 families, comprising 13.8 percent of the total.

Along with the positive changes in declining number of "poor" households as mentioned above, the authors also

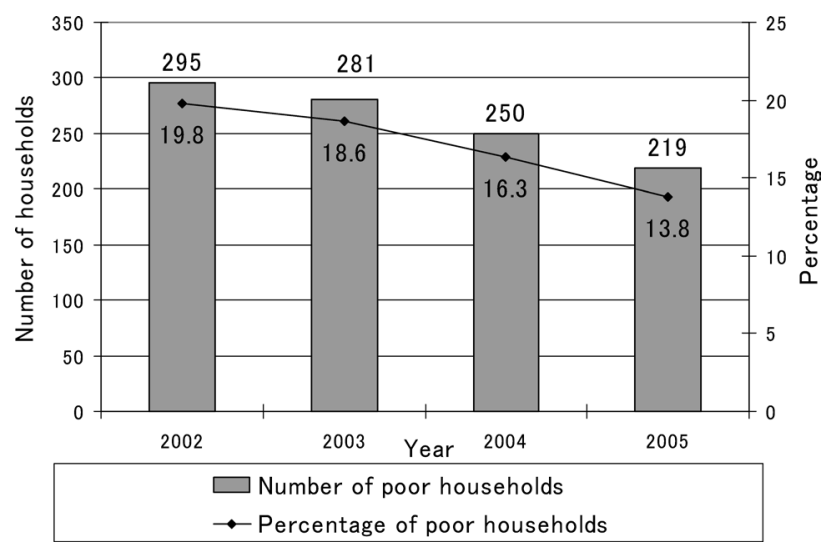

Figure 6. The proportion of poor households reduced between 2002-2005 in Phu An Commune Source: Phu An People's Committee, 2006.

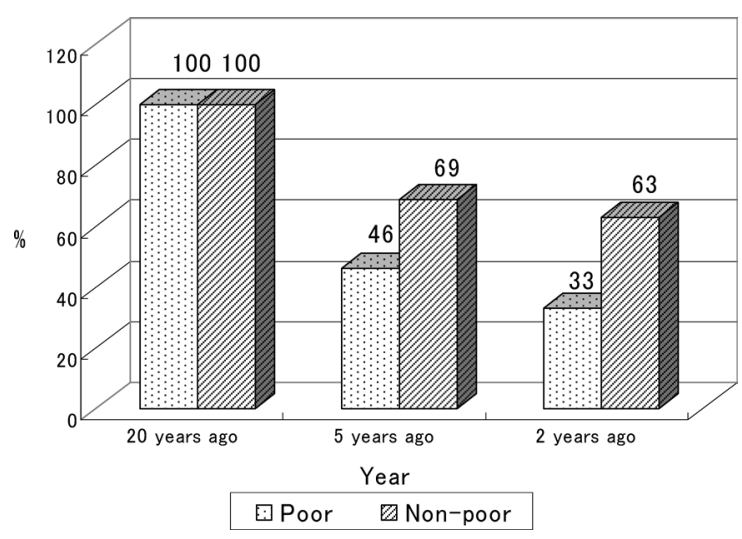

Figure 7. Percentage of respondents with positive views on the improvement of life compared with the past

Source: Author's survey, 2006.

carried out interviews to identify the residents' views on the changes of their lives over last 20 years. The results are shown in Figure 7.

The results show that almost all respondents think that their lives at present are much better than 20 years ago (when the "Doi Moi" program began). In particular, the non-"poor" households had overwhelmingly positive responses. However, although the "poor" households generally agree that their lives are better than 20 years ago, some complained that their lives have deteriorated over the last five years and two years. This negative thinking by the "poor" can be explained by the rapid aquaculture development without detailed planning, because:

i) it narrowed the common fishing ground used by groups which completely depend on the natural resources of the lagoon.

ii) failures in shrimp aquaculture due to epidemic diseases, caused the death of shrimp and fish, which in turn increased the debts owed by members of the "poor" groups to the bank. 


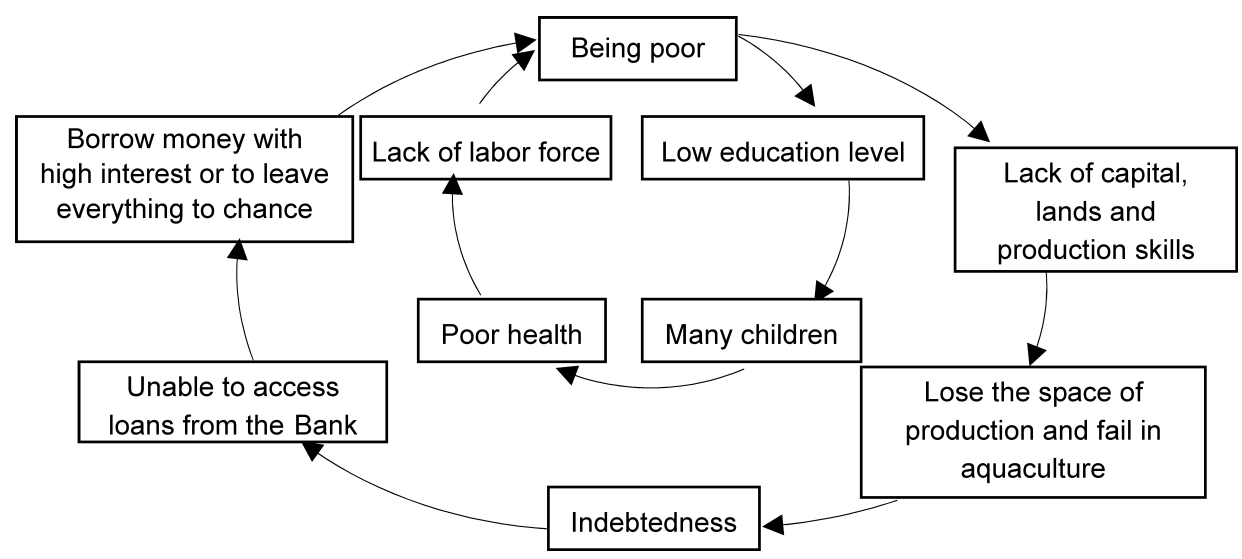

Figure 8. Vicious circle of the poor in Phu An Commune

\section{The Vicious Circle of the Poor in Phu An Commune}

By investigating the characteristics of households, as shown above, and as a result of in-depth interviews with the local residents and the officials of Phu An Commune, the authors have recognized the vicious circle of the poor. This is shown in Figure 8. The inside circle indicates that due to low education levels, the poor have little knowledge of birth-control and attempt to take care of their own health. Various factors, including having too many young children, illness, and annual natural disasters such as typhoons and floods, all contribute to the loss of the main labor forces of households. This leads to a decrease in main income and puts the poor into an extremely difficult position. This may seem contradictory, as a family containing many children should have a large labor force. However, in poor households, the children are often still of school age or younger. They are therefore, unable to contribute earnings to the family. Moreover, in households with many children, housewives have to stay at home to look after them. As a result, these households lose an important income resource and face extreme poverty.

In the outside circle, inhabitants of poor households are not sufficiently equipped with knowledge and techniques of aquaculture. They also have no land and not enough capital to invest in shrimp aquaculture. They are still dependent on the natural resources provided by the lagoon for their daily needs. For households who participate in shrimp aquaculture, although a success of shrimp aquaculture in the initial year may improve their life significantly, epidemic diseases of shrimps often happen in subsequent crops and many households cannot recover enough of the initial capital they invested in shrimp aquaculture, to pay back the bank or lenders.
These households become debtors and they cannot continue to borrow money from the bank because they have no security for a loan. Some households have returned land lent for aquacultural purposes to the local government and returned to traditional fishing on the lagoon. As a result, failures in shrimp aquaculture and mounting debts have brought difficult circumstances to such households.

\section{Conclusion}

This research has presented an overview of the realities of the "poor" in Phu An Commune and the difficulties they face. Our results show that agricultural and aquacultural changes following implementation of the "Doi Moi" policy in 1986 have diversified the local's lives. Positive changes are reflected by a decline in the number of "poor" households, as well as by their own evaluation of their lives in comparison with 20 years ago. Our research identifies that under present agricultural policy and aquacultural development, poverty in the Phu An Commune is not merely a matter of low income, as indicated by the Vietnamese Government, but it is a matter of multifaceted factors, also incorporating a lack of productive resources such as labour force and credit capabilities and improper allocation of arable lands and water surface area for aquacultural purpose.

This research shows that it is difficult for the poor groups to escape from the vicious circle of poverty, due to a lack of main labour forces, an unstable income and many dependants. Moreover, low education is a major obstacle for the poor households, because they do not have the knowledge to approach new techniques and skills in shrimp aquaculture, as well as to adapt to the market system. Many "poor" households have invested in cultivating shrimp and fish with the hope of gaining 
a higher income. But in fact, there is little market for the farm and marine products. Their products, such as shrimp and fish, are mainly sold at the local market within the commune or in the surrounding area. Some households can only sell their products through middlemen generating low prices, since they have limited understanding of marketing systems. Although each household is considered as an economic unit, its size is small, and each household must find a market for their produce individually. In Phu An Commune, there is no large-scale commercial association to mediate profitable interactions between the producers and their market. It can be said that co-operation between households in agricultural and aquacultural activities, and in consumerism is weak.

Recently, epidemics caused shrimp aquaculture to fail and, the poor could not retrieve enough of their invested capital. Some households have returned the lands set aside for aquacultural purposes to the local government and are looking for other work. Others continue to keep their lands but they do not invest in them as they did before.

With the implementation of the "Doi Moi" policy and the consequent introduction of shrimp aquaculture since 1999, the water surface of Tam Giang Lagoon, which used to be an open-access common resource, has been allocated to households and exclusively exploited mainly for shrimp aquaculture. Due to these drastic changes in local resource use, the "Sampan people" who have been engaged in only fishery in the Tam Giang Lagoon, have changed their position in the commune, going from the greatest beneficiaries to those making the greatest sacrifice. Now the poorest people in this area are those who engage in mobile gear fishing, the "Sampan people".

As mentioned in the section discussing land assets, agricultural land and parts of the water surface of the Tam Giang Lagoon used for aquacultural purposes, have been allocated to farmers and fishers. This can create new opportunities for the non- "poor" groups to diversify their economic activities and invest in shrimp aquaculture using earth ponds and net-enclosures. However, the encroachment of water surface of Tam Giang Lagoon by some individuals, in the process of the aquacultural development, has resulted in a decline in the acreage of common fishing grounds available for exploiting aquatic resources. This may bring further vulnerability to the poor who entirely depend on the lagoon's resources, in particular the "Sampan people", and potentially lead to social conflicts among the locals in the Phu An Commune, as well as between communities surrounding the Tam Giang Lagoon.

In this paper, we do not describe in detail the social mobility, which has occurred in the process of resource management change in the Tam Giang Lagoon. Our next paper will deal with this topic with the relation to the process of use and allocation of land and the water surface.

\section{Acknowledgements}

The authors thank the residents of Phu An Commune for their help during our survey period. Thanks also go to the President of Phu An Commune and other officials in Phu An People's Committee for showing a serious interest in this research. Special thanks to the anonymous reviewers for their valuable comments. We also thank Mr. Andrew Fulton and Dr. Zenobia Lewis for their proofreading of the paper.

\section{Notes}

1. The spring paddy crop is cultivated from December to April while the summer paddy crop is grown from May to September.

2. This is a lagoon area-enclosure with net layers in which the household owners practice fishing in combination with aquaculture.

3. An earth pond is a man-made pond used for shrimp aquaculture. Its area is between $500 \mathrm{~m}^{2}$ and one hectare.

4. When an owner of a fishing corral ground tried to convert all their fishing corral grounds over 1.5 hectares into aquaculture surface, he or she had to borrow the name of other households who had converted their grounds into aquacultural surface less than 1.5 hectares to form an "aquaculture team". The numbers of these memberships were often equal to the number of hectares of the surface area.

5. An earth dike is a man-made dike. It is surrounded the ponds used for shrimp aquaculture.

6. The single net is an instrument made of polymer, which surrounds an area of the water surface in the lagoon for raising shrimp, fish and crabs.

7. This is similar to a single net but it is surrounded by many layers.

8. The total number of the "poor" households on the list was 219.

9. This is a Japanese word, but recently it has been adopted by the Vietnamese to describe people who are in the employ of others as house workers.

10. The Land Law promulgated in September 1993, based on the new Constitution 1992 and Vietnamese Government's guiding, has set concrete stipulations on land management. The ultimate principle for land management is that "Land belongs to all people under the State's uniform management". Article 2 of the 1993 Land Law reads "Users of land on a 
stable basis, that are certified by communal, ward or township People's Committee, will be considered and granted land use certificates by a competent State authority."

11. The local people themselves can also classify and give criteria about a sense of well-being by looking at themselves and their neighbors. They identify their difficult situation not only through a lack of food and low income, but also through a lack of housing, clothes, simple furniture and other assets.

\section{References}

Beckman, M. 2001. Extension, poverty and vulnerability in Vietnam. Working paper 152. Swedish University of Agriculture Sciences.

Centre for International Economics, Canberra and Sydney 2002. Vietnam poverty analysis. Australian Agency for International Development.

Economic and Social Commission for Asia and the Pacific 1999. Poverty concepts and measurement in developing ESCAP countries. Report of United Nations ESCAP Secretariat, Bangkok, Thailand.

Gutman, J., Takeda, M., and Plant, M. 2006. Poverty reduction strategy paper annual progress report. International Development Association And The International Monetary Fund 〈http://www.imf.org/external/pubs/ft/scr/2006/cr06337. pdf $\rangle$.

Japan Bank for International Cooperation 2003. Agriculture and rural development sector in the Socialist Republic of Viet Nam. Sanyu Consultants Inc.

Markanday, A. 2004. Scaling up IFAD's experience with decentralized and participatory rural development and poverty reduction in Vietnam. Paper presented in the conference Shanghai, China $\langle$ http://www-wds.worldbank.org/〉.

Martin, R., Nguyen Nguyet Nga, Rob Swinkels and Carrie Turk 2003. Vietnam development report: Poverty. Vietnam Development Information Center 〈http://www.vdic.org.vn/〉.
Ministry of Labor, Invalids and Social Affais 2001. Chien luoc xoa doi giam ngheo 2001-2010 (Strategy for hunger eradication and poverty reduction 2001-2010). Office of Ministry of Labor, Invalids and Social Affais. (V)

Ministry of Planning and Investment 2002. Chien luoc tang truong va giam ngheo toan dien (The comprehensive poverty reduction and growth strategy). Vietnam's Government Office. (V)

Naseem, S. M. 1999. Conceptual and estimation issues in the incidence and alleviation of poverty. Economic and Social Commission for Asia and the Pacific. Seminar on Poverty Statistics, Bangkok, Thailand.

Nguyen, T. T. 2002. An assessment of gender roles in livelihood activities of Tan Duong villagers. Coastal Resources Research Network, Dalhousie University, Canada 〈http://idl-bnc.idrc. ca/dspace/handle/123456789/31836 $>$.

Phu An People's Committee 2004. Bao cao qui hoach su dung dat xa Phu An, huyen Phu Vang den nam 2010 (Report on land use planning in Phu An Commune, Phu Vang District until 2010). Unpublished. (V)

Phu An People's Committee 2005. Ke hoach don dien doi thua o xa Phu An, huyen Phu Vang, tinh Thua Thien Hue (Project for re-arrangement land in Phu An Commune, Phu Vang District, Thua Thien Hue Province). Unpublished. (V)

Phu An People's Committee 2006. Bao cao ket qua thuc hien ke hoach phat trien kinh te xa hoi giai doan 2001-2005 (Report on results of plan for socioeconomic development during the period of 2001-2005). (V)

Truong, V. T., and Brzeski, V. 1998. Toward an improved management of common property in Tam Giang Lagoon, Vietnam. Working paper for 7th IASCP Conference Vancouver, Canada.

World Bank 1999. Vietnam development report 2000: Attacking poverty. World Bank〈http://www-wds.worldbank.org/〉.

$(\mathrm{V})$ : written in Vietnamese 